\title{
Peningkatan Sikap Rasa Ingin Tahu dan Peduli Lingkungan dan Kesehatan Menggunakan Model Discovery Learning pada Mahasiswa S-2 Pendidikan Dasar
}

\begin{abstract}
Abstrak
Oleh: Endang Widi Winarni

Penelitian ini bertujuan untuk mendeskripsikan aktivitas pembelajaran, sikap rasa ingin tahu, dan peduli lingkungan/kesehatan menggunakan model Discovery Learning. Jenis penelitian ini adalah Penelitian Tindakan Kelas (PTK) atau Classroom Action Research yang dilaksanakan sebanyak 3 siklus. Subyek dalam penelitian ini adalah mahasiswa yang mengikuti perkuliahan IPA Pendidikan Dasar semester I pada Prodi S-2 Pendidikan Dasar FKIP UNIB Tahun 2018/2019 yang berjumlah 33 mahasiswa. Instrumen penelitian lembar pengamatan (observation) keterlaksanaan pembelajaran, sikap rasa ingin tahu, dan peduli lingkungan/kesehatan. Analisis data hasil observasi keterlaksanaan pembelajaran, sikap rasa ingin tahu, dan peduli lingkungan/kesehatan dilakukan secara deskriptif. Hasil yang dicapai yaitu: (1) enam langkah pembelajaran menggunakan model diskoveri learning dapat dilaksanakan dengan baik. (2) persentase sikap rasa ingin tahu pada siklus I sebesar 53,54\% meningkat menjadi $72,73 \%$ pada siklus II, dan meningkat menjadi $90,91 \%$ pada siklus III. (3) persentase sikap peduli lingkungan/kesehatan pada siklus I sebesar $57,58 \%$ meningkat menjadi $60,61 \%$ pada siklus II, dan meningkat menjadi $87,88 \%$ pada siklus III. Simpulan bahwa penerapan model Discovery Learning dapat meningkatkan aktivitas pembelajaran, sikap rasa ingin tahu, dan peduli lingkungan/kesehatan mahasiswa S-2 Pendidikan Dasar FKIP Unib dalam perkuliahan IPA Pendidikan Dasar. Saran yang diberikan kepada guru dan atau peneliti selanjutnya sebagai berikut: (1) dalam menerapkan model Discovery Learning kunci utama dari sintaks adalah tahap stimulasi karena dapat berdampak pada efektifnya langkah diskoveri learning selanjutnya. (2) Kepada peneliti selanjutnya dan praktisi di SD disarankan menerapkan model diskoveri learning, karena dapat berkontribusi dalam mewujudkan tercapainya tujuan pendidikan IPA di Sekolah Dasar.
\end{abstract}

Kata kunci: Rasa Ingin Tahu, Peduli Lingkungan/Kesehatan, Model Discovery Learning

\section{Pendahuluan}

Perkembangan IPTEK pada saat ini menuntut pada pendidikan yang berkualitas. Pendidikan berkualitas dapat diciptakan pendidik dengan melakukan upaya mengajar, membimbing, dan melatih siswa serta mengarahkan siswa untuk memiliki kemampuan sikap, pengetahuan, dan keterampilan yang dibutuhkan. Hal tersebut sesuai dengan (Acedo dan Hughes, 2014) yaitu pendidikan memegang peranan penting untuk mempersiapkan generasi yang mampu bersaing pada abad 
ke 21 ini, pendidikan juga harus segera diubah atau ditransformasikan dari pembelajaran tradisional menjadi pendidikan modern untuk menjamin peserta didik memiliki pengetahuan, keterampilan belajar dan berinovasi, keterampilan menggunakan teknologi untuk mencari informasi, dan bertahan dengan menggunakan keterampilan untuk life skills.

Karakretistik manusia abad 21. Sumber Daya Manusia seharusnya memiliki sejumlah kompetensi/keahlian antara lain: 1) kemampuan berpikir kritis dan pemecahan masalah (Critical-Thinking and Problem-Solving Skills) 2) kemampuan berkomunikasi dan bekerjasama (Communication and Collaboration Skills) 3) kemampuan mencipta dan membaharui (Creativity and Innovation Skills) 4) literasi teknologi informasi dan komunikasi (Information and Communications Technology Literacy) 5) kemampuan belajar kontekstual (Contextual Learning Skills) 6) kemampuan informasi dan literasi media (Information and Media Literacy Skills).

Dalam abad 21, literasi sains tidak hanya mengukur tingkat pemahaman terhadap pengetahuan sains, tetapi juga pemahaman terhadap berbagai aspek proses sains, serta kemampuan mengaplikasikan pengetahuan dan proses sains dalam situasi nyata yang dihadapi siswa, baik sebagai individu, anggota masyarakat, serta warga dunia. Kerangka kerja literasi sains dalam PISA 2015 meliputi empat area, yakni: konteks, kompetensi, sikap, dan pengetahuan.

Dari empat area yang disebutkan di atas salah satu yang menjadi fokus yaitu sikap sains khususnya sikap rasa ingin tahu dan peduli lingkungan/kesehatan. Sikap ini harus dimiliki siswa dalam setiap pembelajaran guna untuk menghadapi berbagai permasalahan di masa yang akan datang.

Pengembangan sikap pada diri siswa menjadi misi imbas namun sangat penting bagi pendidikan saat ini. Hasil belajar melahirkan peserta didik yang produktif, kreatif, inovatif, dan afektif melalui penguatan sikap, ketrampilan dan pengetahuan yang terintegrasi. Proses pengembangan sikap tersebut dicapai melalui integrasi nilai-nilai karakter dalam kurikulum. Jadi dalam pembelajaran guru tidak hanya mengajarkan pengetahuan dan keterampilan namun secara tidak langsung juga menumbuhkan dan menguatkan karakter siswa. Kedua kompetensi tersebut (sikap dan spiritual) dicapai melalui pembelajaran tidak langsung 
(indirect teaching), yaitu melalui keteladanan, pembiasaan, dan budaya sekolah; dengan memperhatikan karakteristik mata pelajaran serta kebutuhan dan kondisi peserta didik. Penumbuhan dan pengembangan kompetensi sikap dilakukan sepanjang proses pembelajaran berlangsung dan dapat digunakan sebagai pertimbangan guru dalam mengembangkan karakter peserta didik lebih.

Rasa ingin tahu, merupakan suatu tingkah laku untuk mengetahui dan terus mencari tahu terhadap suatu permasalahan. Rasa ingin tahu adalah cara berpikir, sikap dan perilaku yang mencerminkan penasaran dan keingintahuan terhadap segala hal yang dilihat, didengar, dan dipelajari secara lebih mendalam. Rasa ingin tahu merupakan modal awal bagi siswa dalam proses pembelajaran (Ameliah, dkk, 2016:10). Dengan keingintahuan yang tinggi maka siswa akan belajar lebih menemukan.

Peduli lingkungan/kesehatan adalah sikap dan tindakan yang selalu berupaya mencegah kerusakan pada lingkungan alam/kesehatan di sekitarnya dan mengembangkan upaya-upaya untuk memperbaiki kerusakan alam/kesehatan yang sudah terjadi. Dengan peduli lingkungan/kesehatan siswa tidak hanya memiliki tentang pemahaman tentang pentingnya kelestarian lingkungan di sekitar melainkan juga pentingnya menjaga kesehatan diri dan orang lain. Praktik penguatan sikap rasa ingin tahu dan peduli lingkungan/kesehatan dapat diwujudkan dengan model pembelajaran yang relevan. Sikap tersebut secara bertahap atau bersamaan terimplementasi dalam perilaku siswa.

Discovery Learning didefinisikan sebagai model pembelajaran yang tidak menyampaikan keseluruhan materi. Materi disampaikan secara terpisah hanya sebagian saja yang disampaikan secara langsung, sedangkan yang lainnya di temukan sendiri oleh siswa. Siswa didorong untuk aktif dalam menemukan bagian pengetahuan yang belum disampaikan. Secara utuh siswa membangun suatu konsep dan generalisasi dari pecahan temuan-temuan yang mereka dapatkan. Guru membimbing siswa untuk menemukan dan membangun konsep serta generalisasi. Model Discovery Learning adalah teori belajar yang didefinisikan sebagai proses pembelajaran yang terjadi bila pelajar tidak disajikan dengan pelajaran dalam bentuk finalnya, tetapi diharapkan mengorganisasi sendiri. Proses pembelajaran menggunakan model pembelajaran Discovery (penemuan) 
dirancang sedemikian rupa di mana siswa menggunakan kemampuan mental intelektual sendiri dalam memecahkan berbagai persoalan yang dihadapi, sehingga menemukan suatu konsep atau generalisasi yang dapat diterapkan dalam kehidupannya. Winarni et all (2018: 73) memperoleh kesimpulan bahwa penggunaan model discovery learning dalam pembelajaran Tematik terpadu berpengaruh secara signifikan dalam meningkatkan pengetahuan dan sikap sosial siswa. Sejalan dengan itu, Hasil penelitian oleh Ulum, dkk (2015:75) menunjukkan hasil bahwa penerapan model discovery learning dapat meningkatkan sikap berani mengajukan pertanyaan, sehingga siswa banyak yang mengajukan pertanyaan untuk menunjang rasa ingin tahu mereka.

Pembelajaran pada perkuliahan IPA-Biologi Pendidikan Dasar secara khusus bertujuan untuk menjelaskan hakikat IPA yang berkaitan dengan konsep pertumbuhan dan perkembangan, makanan sehat, dan ekosistem serta pemanfaatannya dalam memecahkan masalah dalam kehidupan sehari-hari. Mengingat bahwa hakikat IPA mengandung 4 komponen, yaitu sikap, proses, produk, dan aplikasi maka sangat relevan dengan literasi sains. Proses pembelajaran diawali dengan munculnya sikap rasa ingin tahu dan muara hasil belajar yang langsung berdampak bagi kehidupan adalah sikap peduli lingkungan/kesehatan. Perkuliahan selama ini lebih diarahkan pada kajian teoritis melalui kajian pustaka dan jurnal hasil penelitian dan pengukiran hasil belajar cenderung ditentukan dari hasil ujian pengetahuan dan sudah memasukkan aspek sikap, namun persentasenya sangat kecil yaitu 5\% dan itupun digabungkan dengan persentase kehadiran..

Berdasarkan latar belakang di atas, maka tujuan penelitian ini adalah (1) mendeskripsikan aktivitas pembelajaran menggunakan model diskoveri learning, dan (2) mendeskripsikan sikap rasa ingin tahu setelah melaksanakan pembelajaran menggunakan model Discovery Learning, dan (3) mendeskripsikan sikap peduli lingkungan/kesehatan mahasiswa setelah melaksanakan pembelajaran menggunakan model Discovery Learning. 


\section{Metode Penelitian}

Jenis penelitian ini adalah Penelitian Tindakan Kelas (PTK) atau Classroom Action Research. PTK merupakan sebuah kegiatan penelitian yang bertujuan untuk memperbaiki kekurangan-kekurangan yang terdapat dalam pembelajaran di kelas, yaitu dengan cara melakukan tindakan-tindakan tertentu agar dapat memperbaiki serta meningkatkan kualitas proses dan hasil pembelajaran yang diselenggarakan secara profesional (Winarni, 2018). Siklus ini berlangsung beberapa kali sehingga tercapai tujuan yang diinginkan.

Menurut Lewin dalam Winarni (2018b) penelitian tindakan kelas memiliki empat tahap yaitu Planning (perencanaan), action (tindakan), observation (pengamatan) dan reflection (refleksi).

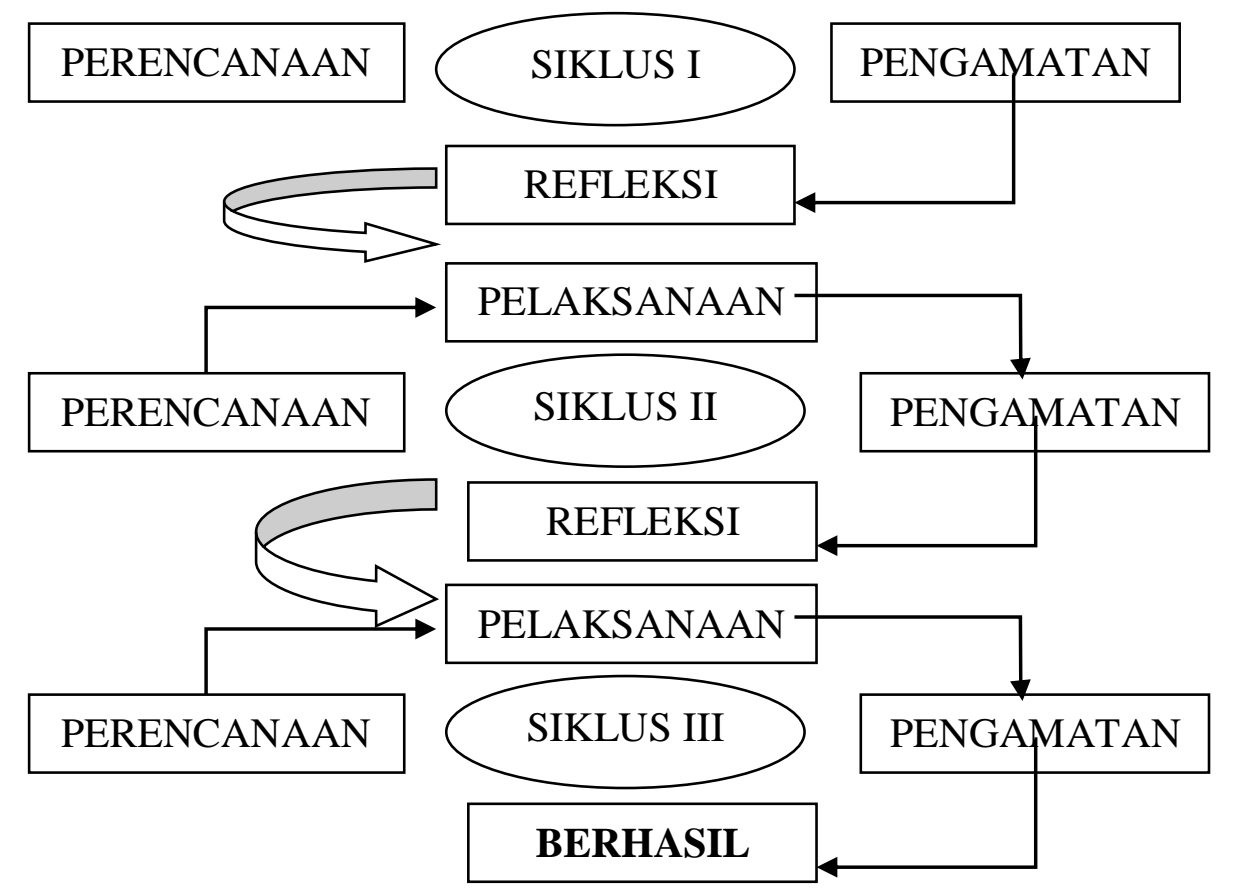

Gambar 1. Alur Pelaksanaan Penelitian Tindakan Kelas

Penelitian ini dilaksanakan di Prodi S-2 Pendidikan Dasar FKIP Universitas Bengkulu pada semester I Tahun 2018/2019. Penelitian untuk Siklus I dilaksanakan pada hari Sabtu, 14 Oktober 2018. Penelitian untuk Siklus II dilaksanakan pada hari Sabtu, 21 Oktober 2018. Penelitian untuk Siklus III dilaksanakan pada hari Sabtu, 28 Oktober 2018. 
Sumber data dalam penelitian ini adalah mahasiswa yang mengikuti perkuliahan IPA Pendidikan Dasar semester I pada Prodi S-2 Pendidikan Dasar FKIP UNIB Tahun 2018/2019 yang berjumlah 33 mahasiswa.

Instrumen dalam penelitian ini yaitu lembar pengamatan (observation) untuk mengamati aktivitas pembelajaran menggunakan model diskoveri, sikap rasa ingin tahu, dan peduli lingkungan/kesehatan. Pengumpulan data dalam penelitian ini yaitu observasi atau pengamatan; pengamatan dilakukan selama proses pembelajaran berlangsung untuk mendesripsikan aktivitas pembelajaran menggunakan model diskovery learning, penilaian aspek sikap rasa ingin tahu, dan peduli lingkungan/kesehatan. Analisis data yang digunakan dalam penelitian ini yaitu data hasil observasi keterlaksanaan pembelajaran, penilaian aspek sikap rasa ingin tahu dan peduli lingkungan/kesehatan dikumpulkan selama proses pembelajaran dengan pemberian skor 1-4 sesuai kriteria masing-masing aspek.

Indikator keberhasilan dalam penelitian ini yaitu: (1) setiap langkah dari sintaks pembelajaran menggunakan model diskoveri mencapai kategori baik, (2) persentase jumlah mahasiswa yang menunjukkan sikap rasa ingin tahu dan peduli lingkungan/kesehatan dengan kategori baik telah mencapai minimal 80\%.

\section{Hasil Penelitian}

Hasil observasi aktivitas pembelajaran langkah model diskoveri learning pada masing-masing siklus dianalisis secara deskriptif sebagai berikut:

Pada siklus I menunjukkan pada tahap: (1) stimulasi, dosen menampilkan powerpoint tentang pertumbuhan dan perkembangan tumbuhan, respon mahasiswa positif dan antusias namun belum aktif mengajukan pertanyaan dan mengajukan pendapat. (2) identifikasi masalah, dosen memfasilitasi pembentukan kelompok, mengidentifikasi masalah dan menerima logistik alat bahan pengamatan, respon mahasiswa saat membentuk kelompok masih santai dan pada saat pembagian logistik perkuliahan sudah antusias. (3) pengumpulan data, dosen memfasilitasi kegiatan pengamatan, pengukuran, dan pencatatan data, respon mahasiswa belum fokus dalam kegiatan pengukuran dan pencatatan hasilnya. (4) pengolahan data, dosen memfasilitasi pengolahan data yaitu menyajikan hasil analisis data dalam bentuk grafik atau diagram tentang pertumbuhan dan 
perkembangan, respon mahasiswa masih belum fokus. (5) pembuktian, dosen mengarahkan kelompok untuk mengecek kembali jawaban LKM materi pertumbuhan dan perkembangan tumbuhan; respon baru dua kelompok dari enam kelompok yang mengecek kembali jawaban LKM. (6) menarik kesimpulan, wakil kelompok menyimpulkan hasil pembuktian tentang pertumbuhan dan perkembangan tumbuhan; respon mahasiswa antusias menyimak grafik pola pertumbuhan dan perkembangan pada tumbuhan.

Pada siklus II menunjukkan pada tahap: (1) stimulasi, dosen menampilkan powerpoint tentang metabolisme pada tubuh manusia yaitu makanan sehat, respon mahasiswa positif dan antusias dan aktif berpendapat, namun belum aktif mengajukan pertanyaan. (2) identifikasi masalah, dosen memfasilitasi identifikasi masalah secara individu kemudian digabungkan menjadi masalah dalam kelompok, respon mahasiswa sudah fokus dan antusias. (3) pengumpulan data, dosen memfasilitasi kegiatan pengamatan, pengukuran, dan pencatatan data, respon mahasiswa sudah fokus dalam kegiatan pengukuran dan pencatatan hasilnya. (4) pengolahan data, dosen memfasilitasi pengolahan data yaitu menyajikan hasil analisis data dalam bentuk tabel tentang kebutuhan energi dan bahan makanan per individu, respon mahasiswa masih belum fokus dan ribut karena masing-masing bertanggungjawab terhadap datanya, perubahan peran ini yang menjadikan situasi pembelajaran ribut. (5) pembuktian, dosen mengarahkan individu dan kelompok untuk mengecek kembali jawaban LKM materi kebutuhan energi dan bahan makanan; respon sudah lima kelompok dari enam kelompok yang mengecek kembali jawaban LKM. (6) menarik kesimpulan, wakil kelompok menyimpulkan hasil pembuktian tentang kebutuhan energi dan bahan makanan; respon mahasiswa antusias menyimak ilustrasi hubungan antara usia, jenis kelamin, berat badan, kualitas aktivitas individu dengan kebutuhan energi dan bahan makanan dalam waktu 24 jam.

Pada siklus III menunjukkan pada tahap: (1) stimulasi, dosen menampilkan powerpoint tentang interaksi komponen abiotik dan biotik dalam ekosistem, respon mahasiswa positif dan antusias dan aktif berpendapat serta mengajukan pertanyaan. (2) identifikasi masalah, dosen memfasilitasi identifikasi masalah secara dalam kelompok, respon mahasiswa sudah fokus dan antusias. (3) 
pengumpulan data, dosen memfasilitasi kegiatan pengamatan, pengukuran, dan pencatatan data yang dilakukan di ekosistem hutan UNIB, respon mahasiswa sudah fokus dan antusias dalam kegiatan pengukuran dan pencatatan hasilnya. (4) pengolahan data, dosen memfasilitasi pengolahan data yaitu menyajikan hasil analisis data dalam bentuk tabel tentang komponen abiotik dan biotik dalam ekosistem hutan, respon mahasiswa sudah fokus dan tertib dalam menggunakan alat dan bahan pengamatan, situasi pembelajaran di luar kelas juga mendukung pemrkuliahan yang sangat menarik bagi mahasiswa. (5) pembuktian, dosen mengarahkan individu dan kelompok untuk mengecek kembali jawaban LKM materi interaksi komponen abiotik dan biotik dalam ekosistem; respon semua kelompok mengecek kembali jawaban LKM. (6) menarik kesimpulan, wakil kelompok menyimpulkan hasil pembuktian tentang interaksi komponen abiotik dan biotik dalam ekosistem; respon mahasiswa sangat antusias menyimak hubungan antara komponen, gejala dan fenomena interaksi abiotik dan biotik dalam ekosistem hutan di UNIB.

Hasil penilaian sikap yaitu berupa lembar observasi sikap rasa ingin tahu dan peduli lingkungan/kesehatan. Sikap dalam penelitian ini mencakup sikap rasa ingin tahu dan peduli lingkungan/kesehatan. Untuk deskriptor sikap rasa ingin tahu, yaitu: (1) mengajukan lebih dari satu gagasan/pendapat; (2) menampilkan sikap antusis dalam melakukan praktikum; (3) mengajukan pertanyaan berdasarkan data dan fakta yang ada; dan (4) menentukan jawaban atas masalah berdasarkan beberapa gagasan yang muncul. Hasil penilaian sikap rasa ingin tahu disajikan pada Tabel 1 .

Tabel 1. Hasil Penilaian Sikap Rasa Ingin Tahu

\begin{tabular}{|c|c|c|c|c|c|c|c|}
\hline \multirow{2}{*}{ No. } & \multirow{2}{*}{ Siklus } & \multirow{2}{*}{ Sikap Sains } & \multicolumn{4}{|c|}{ Persentase Kategori } & \multirow{2}{*}{ Total } \\
\hline & & & $\mathbf{K}$ & $\mathrm{C}$ & B & SB & \\
\hline 1 & I & Rasa Ingin Tahu & $\begin{array}{c}\mathbf{2} \\
(6,06 \%)\end{array}$ & $\begin{array}{c}\mathbf{1 3} \\
(39,40 \%)\end{array}$ & $\begin{array}{c}\mathbf{1 4} \\
(42,42 \%)\end{array}$ & $\begin{array}{c}\mathbf{4} \\
(12,12 \%)\end{array}$ & $100 \%$ \\
\hline 2 & II & Rasa Ingin Tahu & $\begin{array}{c}\mathbf{0} \\
(0 \%)\end{array}$ & $\begin{array}{c}9 \\
(27,27 \%)\end{array}$ & $\begin{array}{c}\mathbf{2 0} \\
(60,61 \%)\end{array}$ & $\begin{array}{c}\mathbf{4} \\
(12,12 \%)\end{array}$ & $100 \%$ \\
\hline 3 & III & Rasa Ingin Tahu & $\begin{array}{c}\mathbf{0} \\
(0 \%)\end{array}$ & $\begin{array}{c}\mathbf{3} \\
(9,09 \%)\end{array}$ & $\begin{array}{c}\mathbf{2 2} \\
(66,67 \%)\end{array}$ & $\begin{array}{c}\mathbf{8} \\
(24,24 \%)\end{array}$ & $100 \%$ \\
\hline
\end{tabular}

Berdasarkan hasil analisis pada Tabel 1, menunjukkan bahwa persentase kategori baik dan sangat baik sikap rasa ingin tahu mahasiswa dari siklus I sebesar $54,54 \%$ ke siklus III sebesar 90,91\% atau mengalami peningkatan sebesar 
$36,37 \%$. Sedangkan persentase mahasiswa yang berada dalam kategori kurang pada siklus I sebesar $6,06 \%$ dan pada siklus II dan III sudah tidak ada mahasiswa yang berada dalam kategori kurang.

Deskriptor sikap peduli lingkungan/kesehatan, yaitu: (1) menunjukkan sikap selalu menjaga kebersihan lingkungan/kesehatan; (2) menunjukkan perilaku peduli lingkungan/kesehatan terhadap sampah; (3) menunjukkan kepedulian lingkungan/kesehatan terhadap tanaman yang ada di sekitar; dan (4) menunjukkan sikap kepedulian lingkungan/kesehatan terhadap kondisi abiotik di sekitar. Hasil penilaian sikap rasa ingin tahu disajikan pada Tabel 2.

Tabel 2. Hasil Penilaian Sikap Peduli Lingkungan/Kesehatan

\begin{tabular}{|c|c|c|c|c|c|c|c|}
\hline \multirow{2}{*}{ No. } & \multirow{2}{*}{ Siklus } & \multirow{2}{*}{ Sikap Sains } & \multicolumn{4}{|c|}{ Persentase Kategori } & \multirow{2}{*}{ Total } \\
\hline & & & K & $\mathrm{C}$ & B & SB & \\
\hline 1 & I & $\begin{array}{l}\text { Peduli } \\
\text { Lingkungan/Kesehatan }\end{array}$ & $\begin{array}{c}\mathbf{1} \\
(3,03 \%)\end{array}$ & $\begin{array}{c}\mathbf{1 3} \\
(39,40 \%)\end{array}$ & $\begin{array}{c}\mathbf{1 6} \\
(48,49 \%)\end{array}$ & $\begin{array}{c}\mathbf{3} \\
(9,09 \%)\end{array}$ & $100 \%$ \\
\hline 2 & II & $\begin{array}{l}\text { Peduli } \\
\text { Lingkungan/Kesehatan }\end{array}$ & $\begin{array}{c}\mathbf{0} \\
(0 \%)\end{array}$ & $\begin{array}{c}\mathbf{1 3} \\
(39,40 \%)\end{array}$ & $\begin{array}{c}\mathbf{1 7} \\
(51,52 \%)\end{array}$ & $\begin{array}{c}\mathbf{3} \\
(9,09 \%)\end{array}$ & $100 \%$ \\
\hline 3 & III & $\begin{array}{l}\text { Peduli } \\
\text { Lingkungan/Kesehatan }\end{array}$ & $\begin{array}{c}\mathbf{0} \\
(0 \%)\end{array}$ & $\begin{array}{c}\mathbf{4} \\
(12,12 \%)\end{array}$ & $\begin{array}{c}\mathbf{1 7} \\
(51,52 \%)\end{array}$ & $\begin{array}{c}\mathbf{1 2} \\
(36,36 \%)\end{array}$ & $100 \%$ \\
\hline
\end{tabular}

Berdasarkan hasil analisis pada Tabel 2, menunjukkan bahwa persentase kategori baik dan sangat baik sikap rasa ingin tahu mahasiswa dari siklus I sebesar $57,58 \%$ ke siklus III sebesar $87.88 \%$ atau mengalami peningkatan sebesar 30,3\%. Sedangkan persentase mahasiswa yang berada dalam kategori kurang pada siklus I sebesar 3,03\% dan pada siklus II dan III sudah tidak ada mahasiswa yang berada dalam kategori kurang.

\section{Pembahasan}

Discovery learning merupakan model pembelajaran yang dikembangkan berdasarkan pandangan konstruktivisme. Oleh sebab itu, pembelajaran diskoveri menuntut proses mental intelektual siswa dalam memecahkan sebuah permasalahan dengan menemukan konsep atau generalisasi yang dapat diterapkan di lingkunga sekitar. Winarni (2018a:189-190) menyatakan bahwa proses penemuan dilakukan melalui kegiatan menyelidiki secara aktif sehingga siswa dapat mentransformasikan informasi yang lebih kompleks, mengecek informasi 
baru dengan yang sudah ada di dalam ingatannya, serta melakukan pengembangan menjadi informasi yang sesuai dengan lingkungan di mana mereka hidup.

Tahap-tahap pembelajaran diskoveri mencakup: (1) stimulasi, dilaksanakan dengan menayangkan powerpoint dikuti dengan menyampaikan pendapat dan tanya jawab; (2) identifikasi masalah, mahasiswa mendiskusikan permasalahan yang ada di dalam Lembar Kegiatan Mahasiswa (LKM); (3) pengumpulan data, mahasiswa berdiskusi dalam mengerjakan LKM; (4) pengolahan data, mahasiswa menganalisis data hasil pengamatan dan hasil kerja kelompok; (5) pembuktian, mahasiswa mengecek kembali jawaban LKM sehingga dapat memutuskan jawaban terhadap hipotesis yang telah dirumuskan; serta (6) menarik kesimpulan. Keenam langkah pembelajaran diskoveri leraning dapat dilaksanakan dengan kategori baik, dan khusus langkah stimulasi dapat dilaksankan dengan sangat baik.

Dampak dari keteterlaksanaan pembelajaran yang baik dan sangat baik tersebut adalah meningkatnya sikap rasa ingin tahu dan sikap peduli lingkungan/kesehatan. Sikap rasa ingin tahu mencakup: (1) mengajukkan lebih dari satu gagasan/pendapat; (2) menampilkan sikap antusias dalam melakukan pengamatan dan pengumpulan data; (3) mengajukan pertanyaan berdasarkan data dan fakta yang ada; dan (4) menentukan jawaban atas masalah berdasarkan beberapa gagasan yang muncul. Hal itu dapat terjadi karena, melalui stimulasi mahasiswa dituntut: (1) mengajukan pertanyaan tentang pengetahuan yang bersifat faktual atau kontekstual, (2) mengingat pengalaman sehari-harinya dan (3) menunjukkan keterkaitannya dengan topik pembelajaran yang dibahas. Sikap peduli lingkungan/kesehatan yang diukur, mencakup: (1) sikap selalu menjaga kebersihan lingkungan/kesehatan; (2) peduli lingkungan/kesehatan terhadap sampah; (3 kepedulian lingkungan/kesehatan terhadap tanaman yang ada di sekitar; dan (4) kepedulian lingkungan/kesehatan terhadap kondisi abiotik di sekitar.

Hasil penelitian Winarni, et all (2018: 72) menunjukkan bahwa melalui tahap: (1) stimulasi dapat membangkitkan rasa ingin tahu, (2) dengan rasa ingin tahunya menjadikan mahasiswa mampu mengidentifikasi masalah dan menentukan rumusan masalah yang paling relevan, serta merumuskan hipotesis, (3) berdasarkan rumusan hipotesis mahasiswa menjadi terarah dalam pengumpulan data serta mendapat kesempatan seluas-luasnya dalam mengumpulkan informasi yang relevan, (4) pengumpulan data yang teliti dan objektif dapat memperkuat dalam pengolahan data, mahasiswa menjawab permasalahan berdasarkan hasil pengolahan data, (5) hasil pengolahan data dijadikan dasar dalaam pembuktian, mahasiswa secara mandiri dapat 
membuktikan hipotesis berdasarkan hasil pengolahan data, dan (6) menarik kesimpulan, mahasiswa mampu menarik kesimpulan berdasarkan hasil pembuktian. Dengan serangkaian langkah tersebut, mahasiswa: (1) memiliki kesempatan belajar penemuan secara aktif, (2) menemukan pola penemuan dalam konteks konkrit maupun abstrak; (3) telah belajar merumuskan strategi tanya jawab dan bekerja sama secara efektif; serta (4) menemukan konsep-konsep dan prinsip-prinsip yang dipelajari melalui penemuan lebih bermakna. Hasil penelitian ini sejalan dengan temuan Fauzi dan Atok (2017) bahwa rasa ingin tahu dapat muncul pada langkah stimulasi karena tahap ini siswa diajak untuk berinteraksi dengan tanya jawab terhadap media yang digunakan sehingga akan merangsang siswa untuk terus bertanya dan bertanya.

Winarni (2018a) menyatakan bahwa penggunaan model Discovery learning dalam pembelajaran tematik berpengaruh secara signifikan terhadap sikap peduli lingkungan, pemahaman tentang kompos bagi siswa SD di Kota Bengkulu. Peningkatan sikap rasa ingin tahu dan peduli lingkungan/kesehatan maha siswa menggunakan model pembelajaran diskoveri ini menjadi penting karena mahasiswa S2 Pendidikan Dasar adalah praktisi di Sekolah Dasar. Pada gilirannya, dapat berkontribusi dalam mewujudkan tercapainya tujuan pendidikan IPA di Sekolah Dasar, yaitu: (1) kesadaran akan keindahan dan keteraturan alam untuk meningkatkan keyakinan terhadap Tuhan Yang Maha Esa. (2) Pengetahuan, yaitu pengetahuan tentang dasar dari prinsip dan konsep, fakta yang ada di alam, hubungan saling ketergantungan, dan hubungan antara sains dan teknologi. (3) Keterampilan dan kemampuan untuk menangani peralatan, memecahkan masalah, dan melakukan observasi. (4) Sikap ilmiah, antara lain skeptis, kritis, sensitif, objektif, jujur terbuka, benar, dan dapat bekerja sama. (5) Kebiasaan mengembangkan kemampuan berpikir analitis induktif dan deduktif dengan menggunakan konsep dan prinsip sains untuk menjelaskan berbagai peristiwa alam. (6) Apresiatif terhadap sains dengan menikmati dan menyadari keindahan keteraturan perilaku alam serta penerapannya dalam teknologi.

\section{Simpulan}

Dari hasil penelitian tindakan kelas dapat disimpulkan bahwa:

1. Model Discovery Learning yang dioperasionalkan dalam tahap-tahap stimulasi, identifikasi masalah, pengumpulan data, pengolahan data, 
pembuktian, dan menarik kesimpulan dapat dilaksanakan dengan baik. Keterlaksanaan pembelajaran diskoveri dapat mendorong mahasiswa: (1) memiliki kesempatan belajar penemuan secara aktif, (2) menemukan pola penemuan dalam konteks konkrit maupun abstrak; (3) telah belajar merumuskan strategi tanya jawab dan bekerja sama secara efektif; serta (4) menemukan konsep-konsep dan prinsip-prinsip yang dipelajari melalui penemuan lebih bermakna.

2. Penggunaan model pembelajaran diskoveri learning dapat meningkatkan skap rasa ingin tahu yang mencakup: mengajukan lebih dari satu gagasan/pendapat; menampilkan sikap antusias dalam melakukan pengamatan dan pengumpulan data; mengajukan pertanyaan berdasarkan data dan fakta yang ada; dan menentukan jawaban atas masalah berdasarkan beberapa gagasan yang muncul.

3. Penggunaan model pembelajaran diskoveri learning dapat meningkatkan sikap peduli lingkungan/kesehatan, yang mencakup kepedulian terhadap: kebersihan lingkungan/kesehatan, sampah, tanaman yang ada di sekitar, dan kondisi abiotik di sekitar.

\section{Saran}

Berdasarkan pembahasan dan kesimpulan di atas, dapat diberikan saran sebagai berikut:

1. Dalam menerapkan model Discovery Learning kunci utama dari sintaks adalah tahap stimulasi. Stimulasi dapat membangkitkan rasa ingin tahu, dengan rasa ingin tahunya menjadikan mahasiswa mampu mengidentifikasi masalah dan menentukan rumusan masalah yang paling relevan, serta merumuskan hipotesis, berdasarkan rumusan hipotesis mahasiswa menjadi terarah dalam pengumpulan data, pengumpulan data yang teliti dan objektif dapat memperkuat dalam pengolahan data sehingga dapat menjawab permasalahan hingga secara mandiri dapat membuktikan hipotesis yang akhirnya mampu menarik kesimpulan berdasarkan hasil pembuktian.

2. Kepada peneliti selanjutnya dan praktisi di SD disarankan menerapkan model diskovery learning, karena dapat berkontribusi dalam mewujudkan 
tercapainya tujuan pendidikan IPA, terutama sikap rasa ingin tahu dan peduli terhadap lingkungan/kesehatan sebagai wujud dari apresiatif mahasiswa/siswa terhadap sains dengan menikmati dan menyadari keindahan keteraturan perilaku alam.

\section{DAFTAR PUSTAKA}

Acedo, C and Hughes. C, (2014), Principles For Learning And Competences In The 21st-Century Curriculum, Journal Springer, 44: 503-525.

Ameliah, I.H., Munawaroh, M., \& Muchyidin, A., (2016) Pengaruh Keingintahuan dan Rasa Percaya Diri Siswa terhadap Hasil belajar Matematika Kelas VII MTs Negeri I Kota Cirebon, EduMa, 5 (1): 9-21. Tersedia: http://syekhnurjati.ac.id/jurnal/index.php/eduma/article/view/598. diunduh tanggal 11 November 2018.

Fauzi A R, Zainuddin., dan Atok R.Al., (2017), Penguatan Karakter Rasa Ingin Tahu Dan Peduli Sosial Melalui Discovery Learning, Jurnal Teori dan Praksis Pembelajaran IPS P-ISSN 2503-1201 | E-ISSN 2503-5307 @ F FIS, Universitas Negeri Malang 2017

http://journal2.um.ac.id/index.php/jtppips/ diunduh tanggal 12 November 2018.

Ulum, D. F, Maridib., \& Yudi R, (2015) Pengaruh Model Pembelajaran Guided Discovery Learning terhadap Hasil Belajar Biologi di SMA Negeri 2 Sukoharjo Tahun Pelajaran 2013/2014. Jurnal Pendidikan Biologi, (Online), $\quad 7 \quad$ (2): 68-79, http://jurnal.fkip.uns.ac.id/index.php/bio/article/download/7373/5147 diunduh tanggal 11 November 2018.

Winarni, E W. 2018b. Teori dan Praktik Penelitian Kuantitatif Kualitatif, Penelitian Tindakan Kelas (PTK) Research and Development (R\&D). Jakarta: Bumi Aksara.

Winarni, E W, 2018a. Pendekatan Ilmiah dalam Pembelajaran Kreatif dan Inovatif. Bengkulu: FKIP UNI Press. ISBN 978-602-8043-73-1.

Winarni, E W., 2012. Inovasi dalam Pembelajaran IPA. Bengkulu: FKIP UNIB. ISBN: 978-602-8043-29-8.

Winarni, E.W; Purwandari, E.P; Lusa, H; and Dadi, S., (2018), The Impact of Thematic Learning Integrated ICT in Tabot Bengkulu As Cultural Ceremony Toward Social Interaction Knowledge in Elementary School. Asian Journal of Education and Training 4.2 (2018): 70-74. 